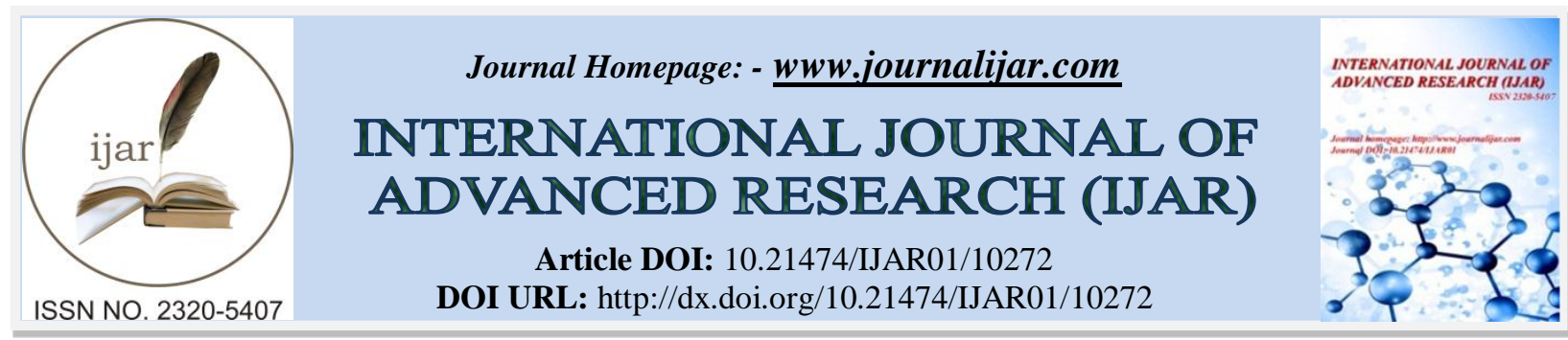

RESEARCH ARTICLE

\title{
FACTORS ASSOCIATED WITH DENTAL FEARS AND ANXIETY IN CHILDREN
}

Dr. Mohsen Daghustani ${ }^{1}$, Hoda Jehad Abousada ${ }^{2}$, Dr. Yara Waleed Al Meer Abdullah ${ }^{2}$, Dr. Najwa Samil Al Qurayqiri $^{2}$, Dr. Zahra Habib Al Saileek ${ }^{2}$, Dr. Shatha Musaad A. Al Harthi ${ }^{2}$, Dr. Noura Salem Al Qahtani ${ }^{2}$ and Dr. Sulafa Aljeelani Fal ${ }^{2}$

1. Consultant Endodontist, Member of the scientific council, Saudi Board of Endodontics, Swedish board in Endodontics, Fellowship in Endodontic Microsurgery, Jeddah Specialty Dental Centre, Ministry of Health.

2. Medicinae Baccalaureus Baccalaureus Chirurgiae, bn Sina National College, KSA (Postal Address: Jjeddah, AlThaghr neighbourhood., 22338.

\section{Manuscript Info}

Manuscript History

Received: 20 November 2019

Final Accepted: 23 December 2019

Published: January 2020

\section{Abstract}

Copy Right, IJAR, 2020,. All rights reserved.

\section{Introduction:-}

The beginning of a dental health in child's is very important especially at a certain age where the child is prone to eat sweets and drink soda. With a lot of damage that may occur in the teeth of the child of caries, infections and abscess sometimes, this requires going to a doctor and treatment. The pain is unbearable and unbearable for children, but many children may refuse to go to the doctor because of fears and anxieties of dental clinics, dentist and even tools.

\section{Rationale:}

Anything related to a child's health is important. Especially the health of teeth, which are greatly affected in the age of children due to the frequent eating sweets and drinking soda. The child's fear and anxiety about going to the dentist may prevent him from treating and complications may increase.

Literature review:

According to the other previous studies, Children's dental fear and anxiety exploring family related factors.

\section{The result was:-}

Children's DFA was not associated with parents' DFA or parenting styles $(\mathrm{p}>0.05) .(\mathrm{Wu}$ and Gao, 2018)

On the other hand, Although the result is not a benefit associated with research, but denial is a step to the beginning of the change in the approach and the beginning of flattering more questions on the subject itself. It did not fully agree with our research in terms of the idea of family history. Our research is limited only to the child and his fears.

We did not find a study that is completely consistent with our study and our goals and most importantly on the subject of factors related to fear and anxiety of dental care in children specifically there is no study in Saudi Arabia.

Corresponding Author:- Hoda Jehad Abousada

Address:- Medicinae Baccalaureus Baccalaureus Chirurgiae, bn Sina National College, KSA (Postal address: Jjeddah, Al-Thaghr neighbourhood., 22338. 


\section{Research Question:}

Questionnaire.

Aim:

The assessment the factors associated with dental fears and anxiety in children.

\section{The Sub- Objectives:-}

1. To determine the most common age suffer from dental fears and anxiety in children.

2. To determine the most common factors associated with dental fears.

\section{Method and Design:-}

Study design:

Cross sectional study.

\section{Study area:}

This study will be conducted in kingdom of Saudi Arabia.

\section{Study setting:}

The study will be carried out by questionnaire.

\section{Study population:}

General children population (IP and OP)

\section{Inclusion criteria:}

Children.

Exclusion criteria:

Adult.

\section{Data Collection Methods:-}

Data collection tool:

Self-administered questionnaire partially constructed by the researcher with reference to already made questionnaire in another study. Validity will be checked by at consultant.

Data collection technique:

The researcher will distribute the questionnaire.

Study sample and technique:

Sample size:

300

Sample technique:

Questionnaire.

Data entry and statistical analysis:

The data will be entered into a personal computer and it will be analyzed using Statistical Package for the Social Sciences (SPSS).

\section{Results:-}

Questionnaire for factors associated with dental fears and anxiety in children. 883 responses were collected showing the following results and conclusion : 


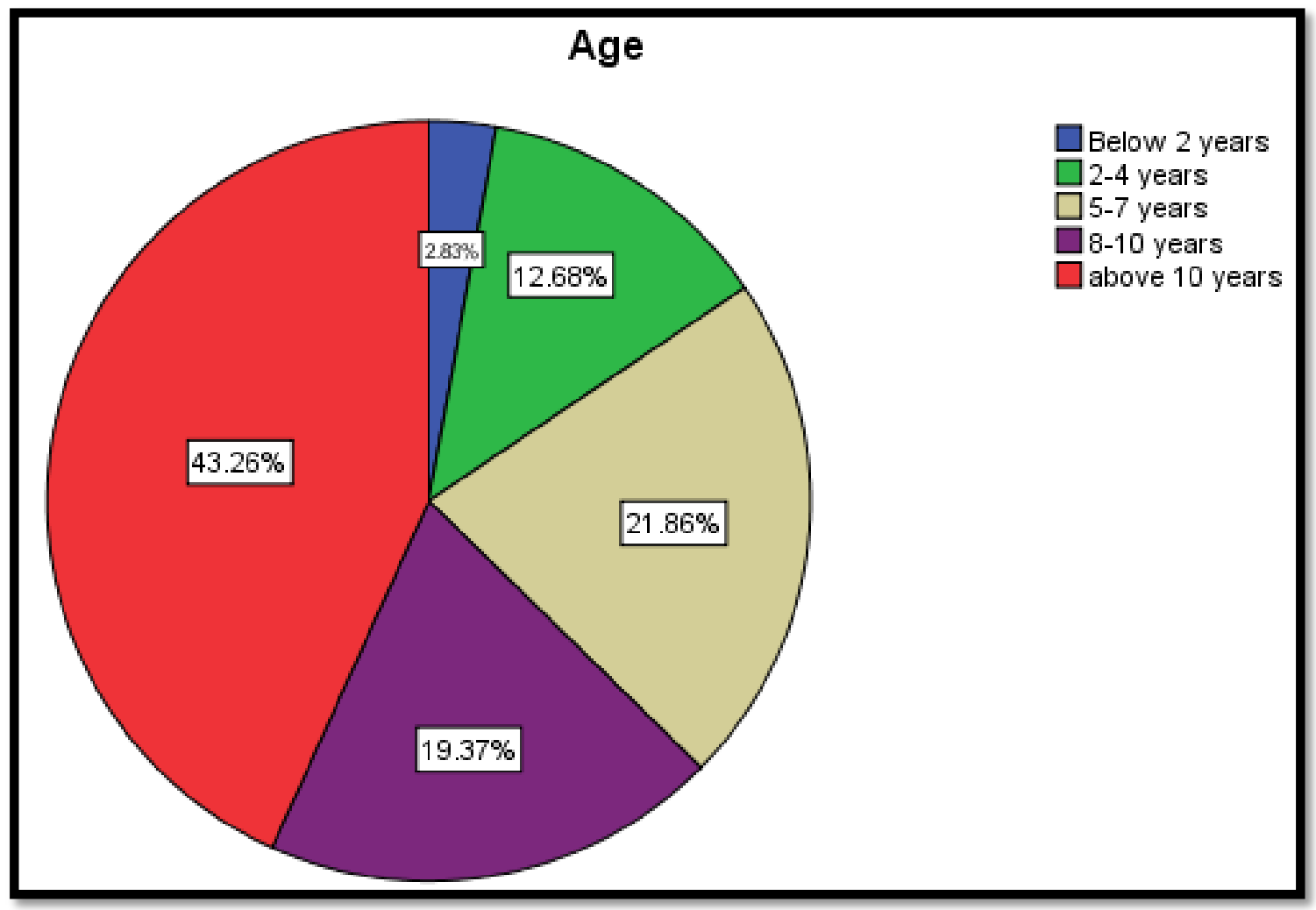

The results indicate that most of the respondents are above 10 years.

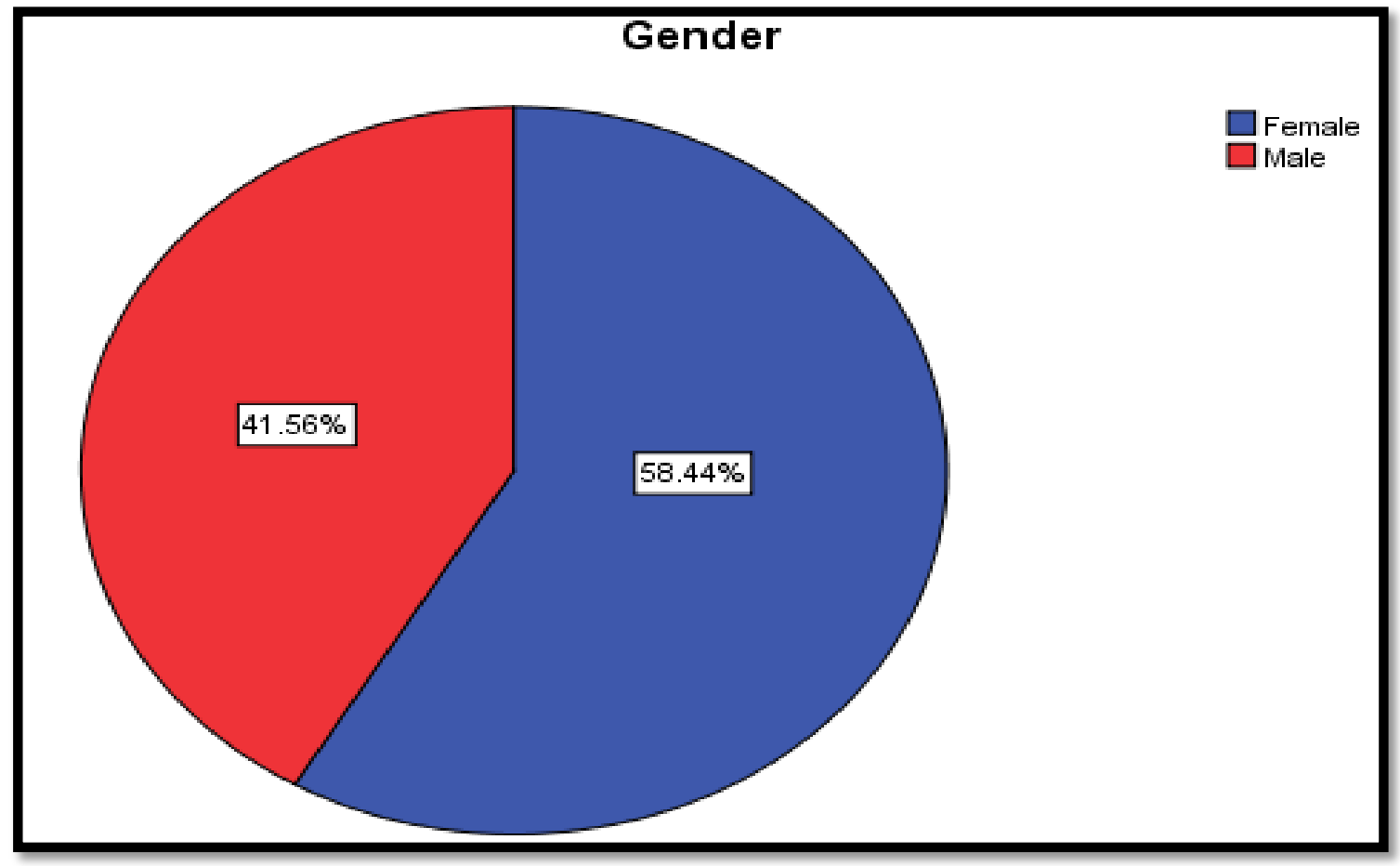

The results indicate that most respondents are females. 


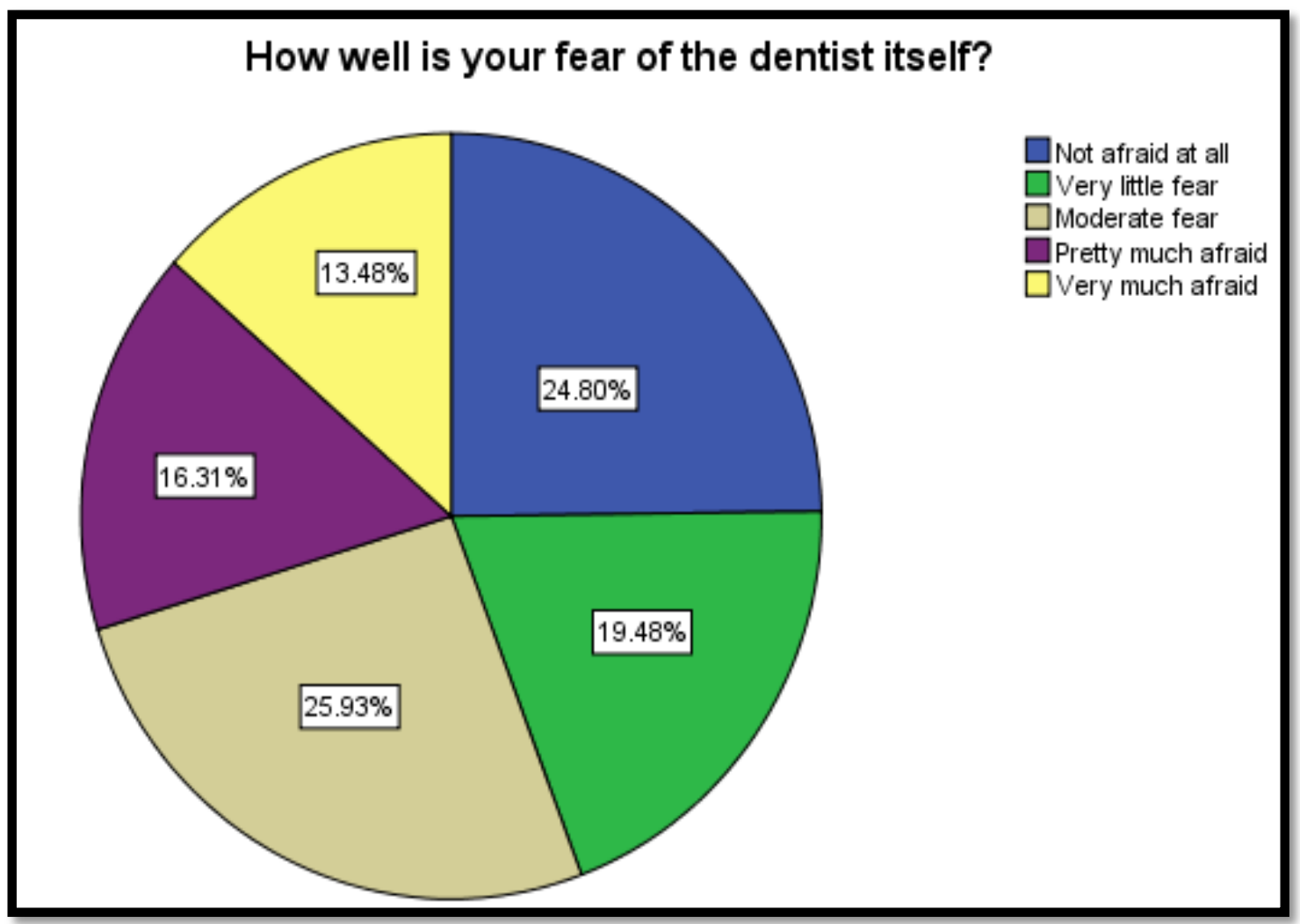

The children's answers differed as to how afraid they were of the dentist himself.

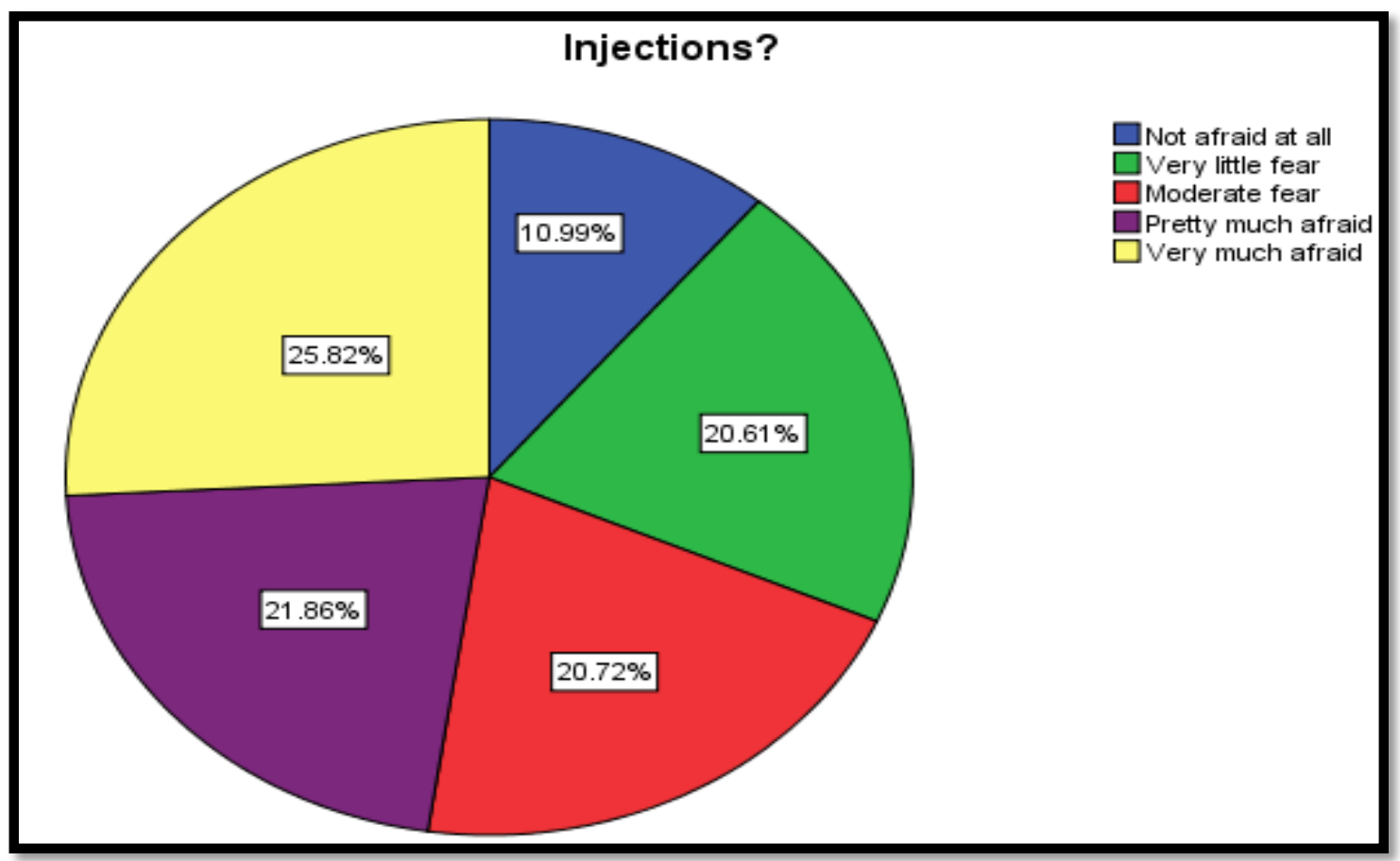

$25.82 \%$ of children are very afraid of injections. 


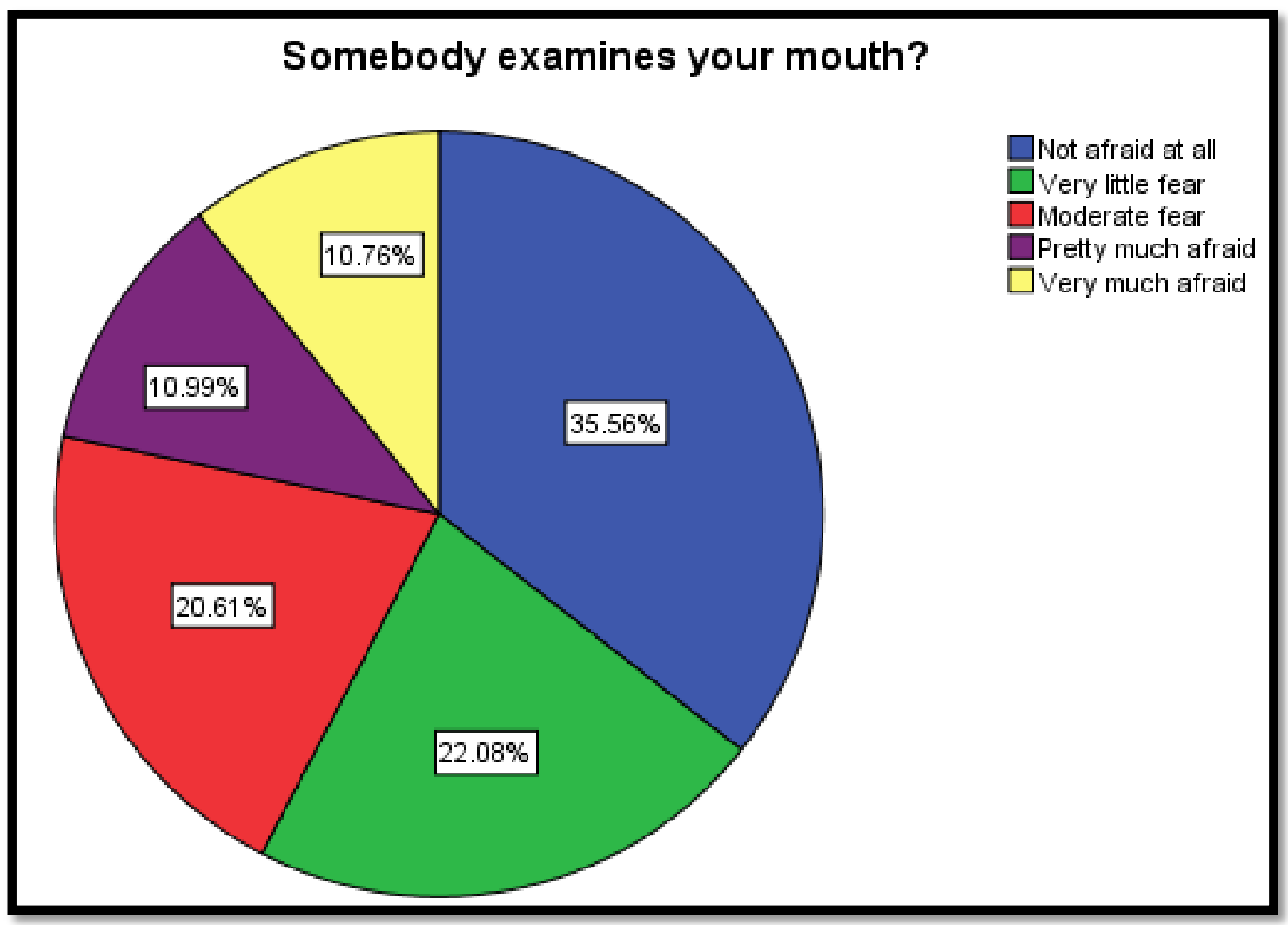

A large percentage of children are not afraid that someone will check their mouth.

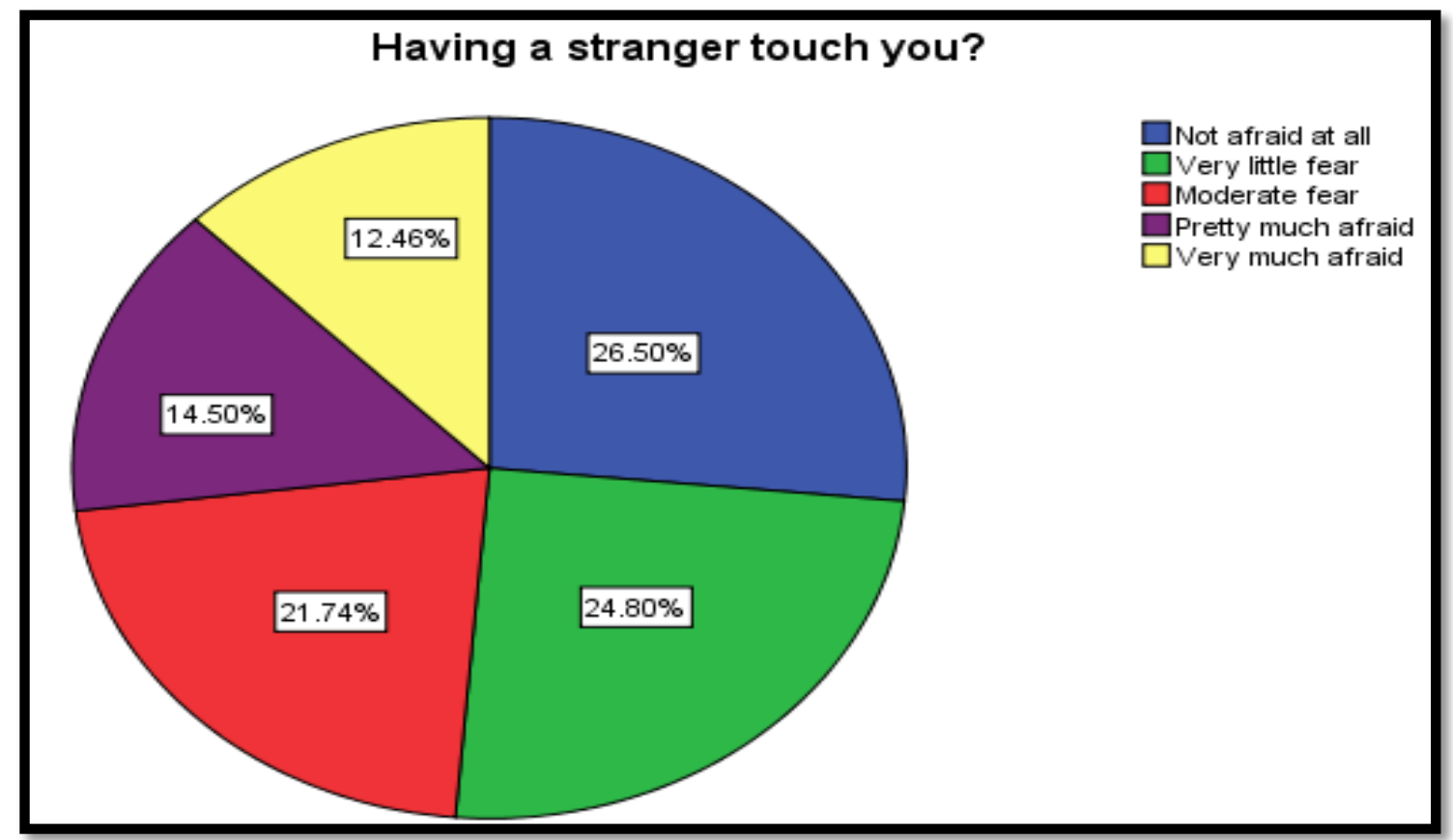

$26.50 \%$ of children are not afraid of having a stranger touch them 


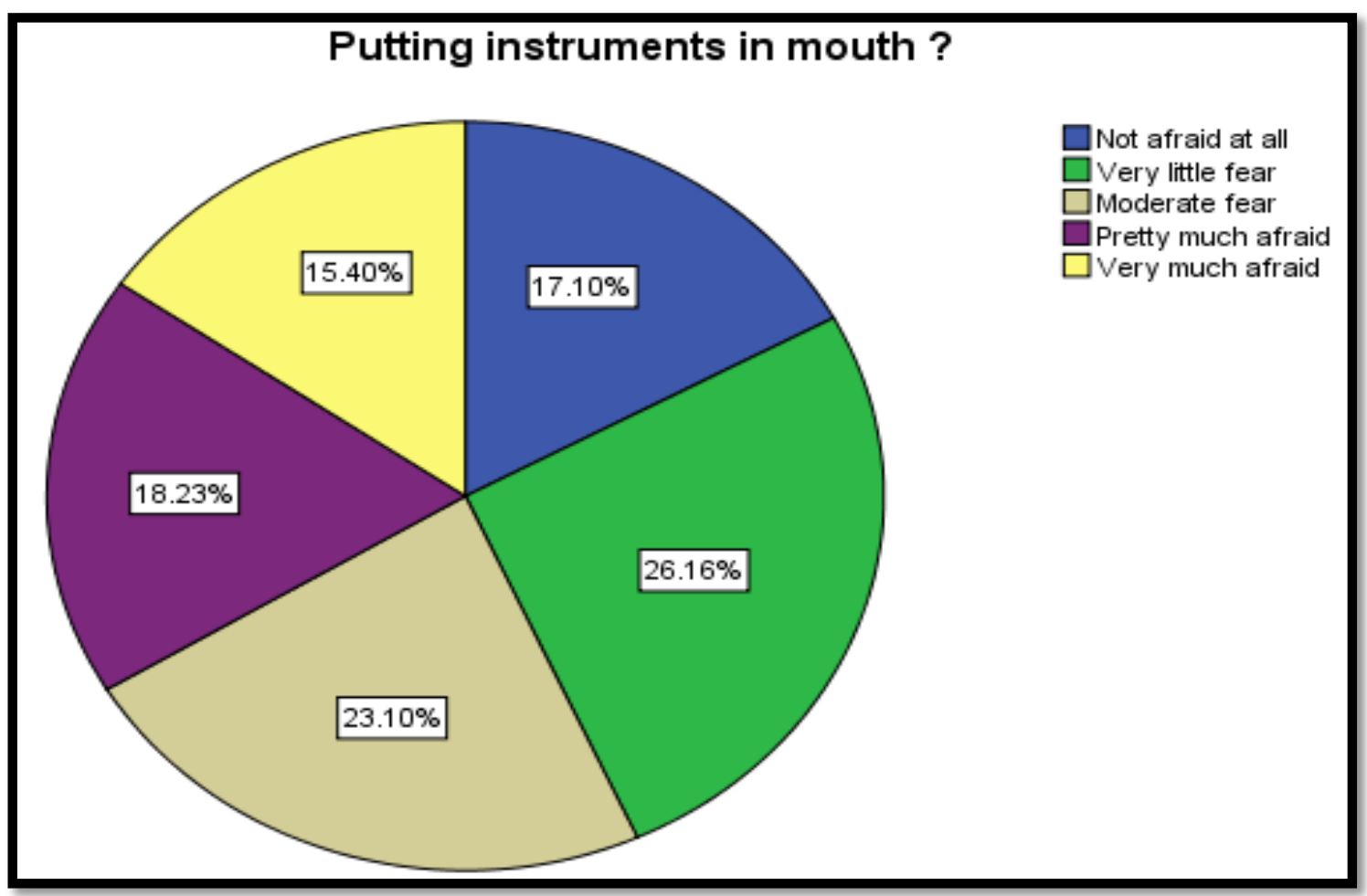

$26.16 \%$ of the children have a very little fear of putting instruments in mouth.

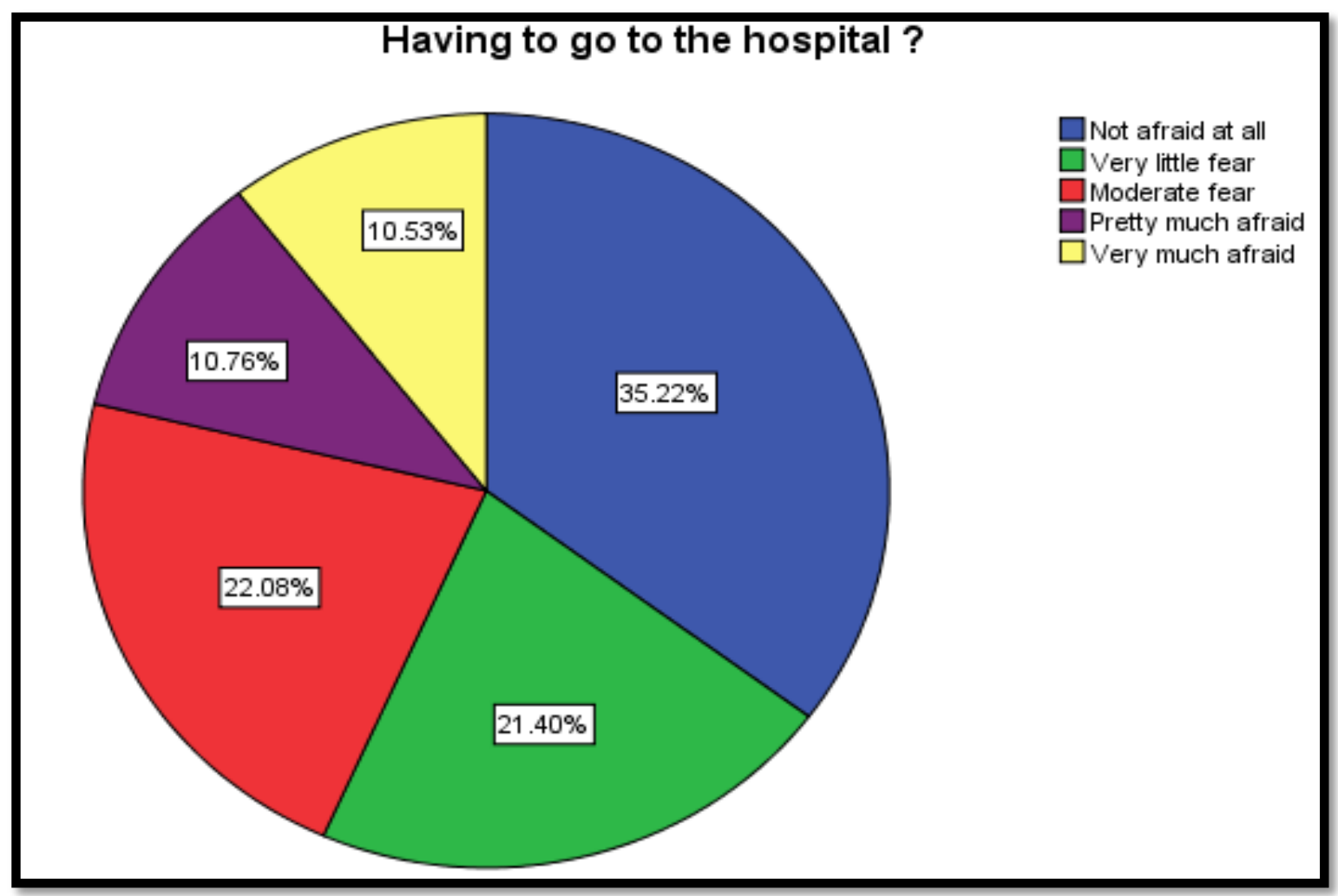

$35.22 \%$ of the children are not afraid at all to go to the hospital . 


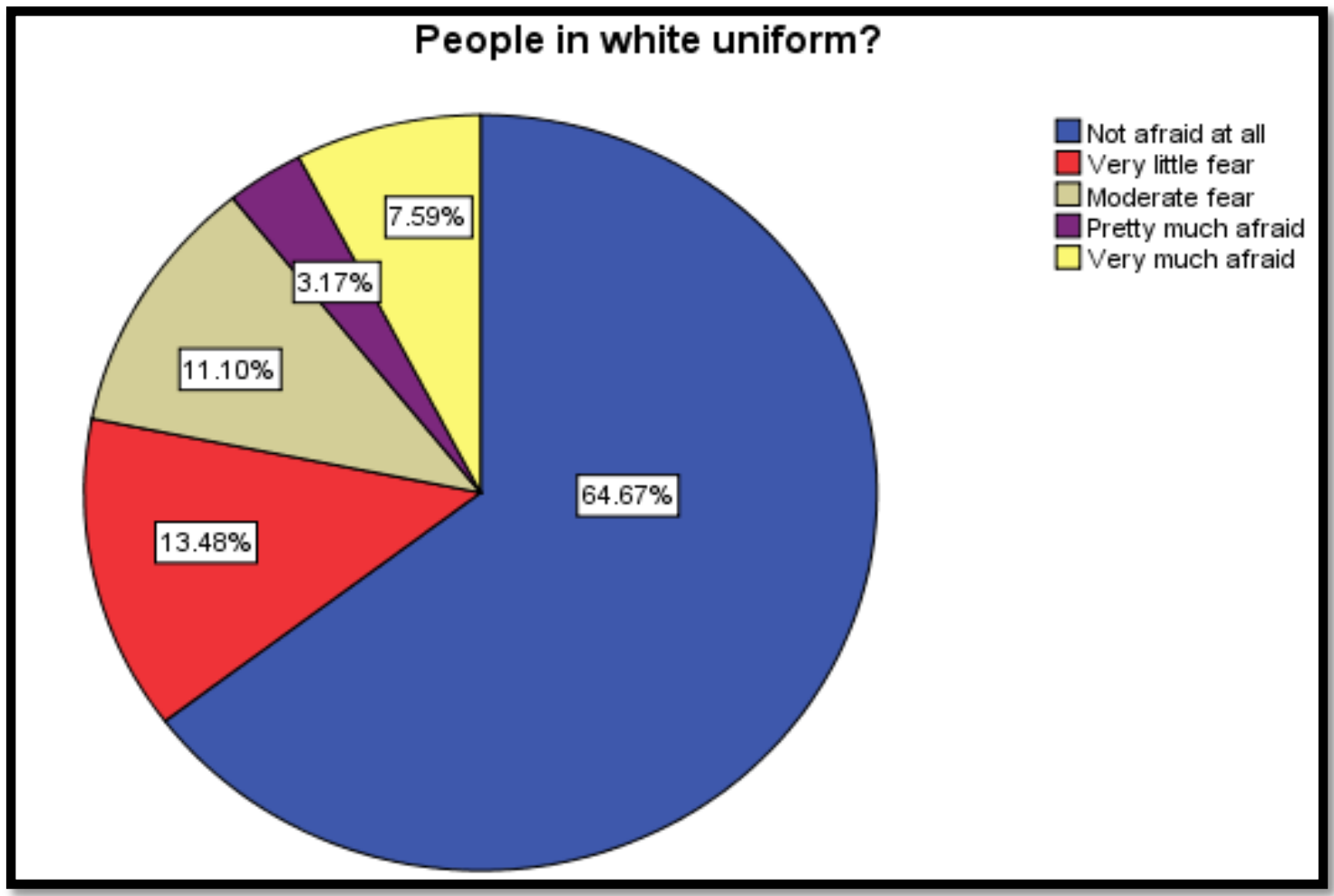

The results indicated that most children are not afraid of people in white uniform.

\begin{tabular}{|c|c|c|c|c|c|c|c|c|c|c|}
\hline \multicolumn{11}{|c|}{ Correlations } \\
\hline & & Age & Gender & $\begin{array}{l}\text { How well is } \\
\text { your fear of } \\
\text { the dentist } \\
\text { itself? }\end{array}$ & Injections? & $\begin{array}{l}\text { Somebody } \\
\text { examines } \\
\text { your mouth? }\end{array}$ & $\begin{array}{c}\text { Having a } \\
\text { stranger } \\
\text { touch you? }\end{array}$ & $\begin{array}{l}\text { Putting } \\
\text { instruments } \\
\text { in mouth? }\end{array}$ & $\begin{array}{c}\text { Having to go } \\
\text { to the hospital } \\
?\end{array}$ & $\begin{array}{l}\text { People in } \\
\text { white } \\
\text { uniform? }\end{array}$ \\
\hline \multirow[t]{3}{*}{ Age } & Pearson Correlation & 1 & $-.142^{\mathrm{xh}}$ & $-.165^{x \pi}$ & $-.222^{\mathrm{xx}}$ & $-.259-^{\mathrm{x}}$ & $-.193^{\mathrm{xx}}$ & $-.206^{\mathrm{xx}}$ & $-.096^{\mathrm{xx}}$ & $-.202^{\text {xh }}$ \\
\hline & Sig. (2-tailed) & & .000 & .000 & .000 & .000 & .000 & .000 & .004 & .000 \\
\hline & $N$ & 883 & 883 & 883 & 883 & 883 & 883 & 883 & 883 & 883 \\
\hline \multirow[t]{3}{*}{ Gender } & Pearson Correlation & $-.142-^{x \pi}$ & 1 & $-.103^{x x}$ & $-.1100^{* \pi}$ & $-.063-$ & $-.151-^{x \pi}$ & $-.076-^{*}$ & $-.106^{* x}$ & $-.055-$ \\
\hline & Sig. (2-tailed) & .000 & & .002 & .001 & .059 & .000 & .024 & .002 & .104 \\
\hline & $N$ & 883 & 883 & 883 & 883 & 883 & 883 & 883 & 883 & 883 \\
\hline \multirow{3}{*}{$\begin{array}{l}\text { How well is your fear of } \\
\text { the dentist itself? }\end{array}$} & Pearson Correlation & $-.165^{* \pi}$ & $-.103^{* \pi}$ & 1 & $.704^{\pi x}$ & $.713^{x \pi}$ & $.646^{\pi x}$ & $.728^{x \pi}$ & $.688^{x \pi}$ & $.553^{x \pi}$ \\
\hline & Sig. (2-tailed) & .000 & .002 & & .000 & .000 & .000 & .000 & .000 & .000 \\
\hline & $N$ & 883 & 883 & 883 & 883 & 883 & 883 & 883 & 883 & 883 \\
\hline \multirow[t]{3}{*}{ Injections? } & Pearson Correlation & $-.2222^{x \pi}$ & $-.110^{\mathrm{x}}{ }^{\pi}$ & $.704^{\pi x}$ & 1 & $.616^{\mathrm{xx}}$ & $.523^{\mathrm{xx}}$ & $.673^{x \pi}$ & $.572^{\pi x}$ & $.420^{\pi \pi}$ \\
\hline & Sig. (2-tailed) & .000 & .001 & .000 & & .000 & .000 & .000 & .000 & .000 \\
\hline & $\mathrm{N}$ & 883 & 883 & 883 & 883 & 883 & 883 & 883 & 883 & 883 \\
\hline \multirow{3}{*}{$\begin{array}{l}\text { Somebody examines your } \\
\text { mouth? }\end{array}$} & Pearson Correlation & $-.259-^{\pi x}$ & $-.063-$ & $.713^{x x}$ & $.616^{x x}$ & 1 & $.734^{\pi x}$ & $.761^{x \times}$ & $.665^{x \pi}$ & $.618^{x x}$ \\
\hline & Sig. (2-tailed) & .000 & .059 & .000 & .000 & & .000 & .000 & .000 & .000 \\
\hline & $N$ & 883 & 883 & 883 & 883 & 883 & 883 & 883 & 883 & 883 \\
\hline \multirow{3}{*}{$\begin{array}{l}\text { Having a stranger touch } \\
\text { you? }\end{array}$} & Pearson Correlation & $-.193^{x \pi}$ & $-.151^{* \pi}$ & $.646^{\pi x}$ & $.523^{x x}$ & $.734^{x \pi}$ & 1 & $.703^{x x}$ & $.632^{x x}$ & $.586^{\mathrm{xx}}$ \\
\hline & Sig. (2-tailed) & .000 & .000 & .000 & .000 & .000 & & .000 & .000 & .000 \\
\hline & $N$ & 883 & 883 & 883 & 883 & 883 & 883 & 883 & 883 & 883 \\
\hline \multirow{3}{*}{$\begin{array}{l}\text { Putting instruments in } \\
\text { mouth? }\end{array}$} & Pearson Correlation & $-.206^{* \pi}$ & $-.076-^{*}$ & $.728^{x x}$ & $.673^{x x}$ & $.761^{\pi \times}$ & $.703^{\mathrm{nx}}$ & 1 & $.678^{x \times}$ & $.567^{\pi x}$ \\
\hline & Sig. (2-tailed) & .000 & .024 & .000 & .000 & .000 & .000 & & .000 & .000 \\
\hline & $\mathrm{N}$ & 883 & 883 & 883 & 883 & 883 & 883 & 883 & 883 & 883 \\
\hline \multirow{3}{*}{$\begin{array}{l}\text { Having to go to the } \\
\text { hospital ? }\end{array}$} & Pearson Correlation & $-.0966^{x x}$ & $-.106^{x x}$ & $.688^{x x}$ & $.572^{x x}$ & $.665^{x x}$ & $.632^{\mathrm{xx}}$ & $.678^{x x}$ & 1 & $.660^{x x}$ \\
\hline & Sig. (2-tailed) & .004 & .002 & .000 & .000 & .000 & .000 & .000 & & .000 \\
\hline & $N$ & 883 & 883 & 883 & 883 & 883 & 883 & 883 & 883 & 883 \\
\hline \multirow[t]{3}{*}{ People in white uniform? } & Pearson Correlation & $-.202^{x x}$ & $-.055-$ & $.553^{\text {xx }}$ & $.420^{\mathrm{xx}}$ & $.618^{\mathrm{xx}}$ & $.586^{x \pi}$ & $.567^{\pi \times}$ & $.660^{\pi x}$ & 1 \\
\hline & Sig. (2-tailed) & .000 & .104 & .000 & .000 & .000 & .000 & .000 & .000 & \\
\hline & $\mathrm{N}$ & 883 & 883 & 883 & 883 & 883 & 883 & 883 & 883 & 883 \\
\hline
\end{tabular}




\section{Discussion:-}

This study was based on a number of 883 participants, from this study as the number of females is 516 and males is 367 and ,119 of them have a big frear of the dentist himself which is considering as unhealthy sign.Also , 228 of them have a big frear of the injections .

The current study showed statistically significant ( $\mathrm{P}$ value is 0.000 ) Which means that there is a strong relationship between the age and the level of fear of the dentist himself, and this means that the patient's age affects the level of fear of doctors, ( $\mathrm{P}$ value is 0.002) Which means that there is a strong relationship between the gender and the level of fear of the dentist himself, and this means that the patient's gender affects the level of fear of doctors.

( $\mathrm{P}$ value is 0.024) Which means that there is a strong relationship between the age and the level of fear of putting instruments in mouth, and this means that the patient's age affects the level of fear of putting instruments in mouth, ( $\mathrm{P}$ value is 0.004$)$ Which means that there is a strong relationship between the age and the level of fear of going to the hospital, and this means that the patient's age affects the level of fear of going to the hospital.

\section{Conclusion:-}

1. Through the questionnaire it was found that injection and needles are one of the most important factors that may cause children to fear dental and doctors.

2. Also, putting doctor's tools in the mouth may cause children to fear the doctors and the hospitals. But the results showed that children are not afraid of any people wearing white uniform in hospitals.

\section{Recommendation:-}

we recommend setting up health education programs about the dental fears and anxiety in children, this problem must be presented broadly and beneficially and, in a way, that everyone understands, as most deal with the dental fears and anxiety in children by ignoring and not being important, work should be done on health conferences and medical discussions on that.

\section{Acknowledgement:-}

The authors would like to thank the participants for their great cooperation, Participants will be especially from medical universities and colleges selected and carried out by questionnaire.

\section{We thank the data collectors:}

Ethical consideration:

1. Individual consent from participants (written on the front page of the questionnaire).

2. All information will be kept confidential.

\section{Budget:}

Self-funded

\section{References:-}

1. Wu, L. and Gao, X. (2018). Children's dental fear and anxiety: exploring family related factors. BMC Oral Health, [online] 18(1). Available at: https://bmcoralhealth.biomedcentral.com/articles/10.1186/s12903-0180553-z [Accessed 2 Oct. 2019].

2. Klingberg G, Broberg AG. Dental fear/anxiety and dental behaviour management problems in children and adolescents: a review of prevalence and concomitant psychological factors. Int J Paediatr Dent. 2007;17:391406.

3. Majstorovic M, Morse DE, Do D, Lim L, Herman NG, Moursi AM. Indicators of dental anxiety in children just prior to treatment. J Clin Pediatr Dent. 2014;39:12-7.

Appendices: (Questionnaire):-

Questionnaire for factors associated with dental fears and anxiety in children.

استبيان عن العوامل المرتبطة بمخاوف الأسنان و القلق عند الأطفال.

Age: العمر

1. Below 2 years/ أقل من سنتين

2. 2-4 years 
3. 5-7 years

4. 8-10 years

5. فوق سن · م سنوات /above 10 years

Gender: الجنس

1. Male / ذنكر /

2. Female / أنثى / Fe

How well is your fear of the dentist itself? مدى مقياس خوفك من طبيب الأسنان بذاته

1. الا أخاف على الإطلاق

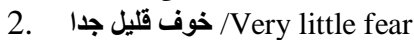

3. خوف معتدل / Moderate fear

4. Pretty much afraid / خوف /

5ائف جدا / Very much afraid خثرا

\section{الحقن ؟ Injections?}

1. ل أخاف على الإطلاق

2. خوف قليل جدات / Very little fear

3. خوف معتدل / Moderate fear

4. نائف كثير / Pretty much afraid / خوف /

5ائف جدا / Very much afraid

شخص يفحص فمك ? Somebody examines your mouth

1. ل الخاف على الإطلاق

2. خوف قليل جلالطاف / Very little fear

3. خوف معتدل جوفل Moderate fear

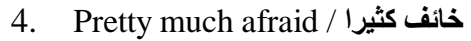

5ائف جذا / Very much afraid

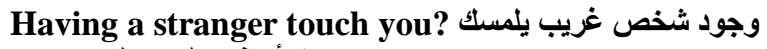

1. ل الا أخاف على الإطلاق

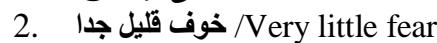

3. خوف معتل جل / Moderate fear

4. تخائف كثيرا / Pretty much afraid

5ائف جدا / Very much afraid

وضع الأدوات في الفم ? Putting instruments in mouth

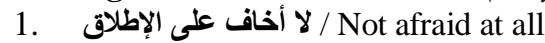

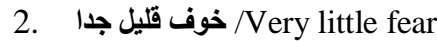

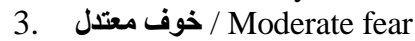

4. تخائف كثيرا / Pretty much afraid

5ائف جذا / خ / Very much afraid

Having to go to the hospital الحاجة إلى الأهاب إلى المستثفى

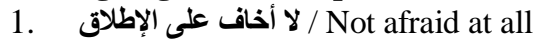

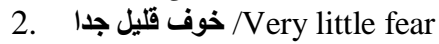

3. خوف معتدل / Moderate fear

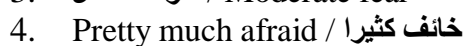

5ائف جدا / Very much afraid

People in white uniform? الناس في الزي الأبيض

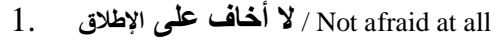

2. وف قليل جداف / Very little fear

3. خوف معتدل

4ائف كثير / Pretty much afraid

5ائف جدا / Very much afraid 